\title{
THE PURIFICATION OF RENNIN-LIKE PROTEASE FROM LACTOBACILLUS PARACASEI ISOLATED FROM ETTAWA GOAT MILK
}

\author{
Wendry Setiyadi Putranto ${ }^{1 *}$, Apon Zaenal Mustopa ${ }^{2}$, Arizah Kusumawati², \\ Anika Prastyowati ${ }^{2}$ \\ ${ }^{1}$ Faculty of Animal Husbandry, Universitas Padjadjaran, Bandung, Indonesia \\ ${ }^{2}$ Research Center for Biotechnology, Indonesian Institute of Science, Cibinong, Indonesia
}

\begin{abstract}
There is a protease produced by bateria that has characteristics similar to rennin from a calf. Rennin has the ability to clot casein in milk. Rennin-like protease (RLP) is produced by bacteria extracellularly. Lactic Acid Bacteria (LAB) have the potential to be developed for RLP production because they are safe and non-pathogenic bacteria. Rennin is needed in the process of milk coagulation to subsequently obtain a curd in the process of making cheese. In this study, the LAB isolated from Ettawa goat milk (isolate 2.12) which produced RLP was 99\% identical to Lactobacillus paracasei based on 16S rRNA gene sequence analysis. The purification of the RLP L. paracasei 2.12 with $60 \%$ ammonium sulfate deposition, dialysis, and filtration gel chromatography Sephadex G-50 showed a single $38 \mathrm{kDa}$ protein band with SMCA/SPA was 4.48 higher than that of the calf rennet with a ratio value of 1 , therefore in this study, RLP L. paracasei 2.12 was developed as an alternative to renin in cheese making.
\end{abstract}

Keywords: Lactobacillus paracasei, rennin-like protease, purification

"Corresponding author:

Faculty of Animal Husbandry, Universitas Padjadjaran, Bandung Tel.+6281380262645

Email: wendry@unpad.ac.id

\section{Introduction}

The cheese industry in Indonesia is not growing. One of the inhibiting factors is the limited availability of the rennin enzyme in the country. This is due to the slaughtering cattle at a young age is not economically beneficial for farmers. Rennin is only produced from the stomach of a calf. So that efforts are needed to produce the protease enzyme that can replace rennin. Some protease enzyme products from plants have been used in making cheese, but have not produced the expected cheese characteristics due to the high proteolytic activity. It produces a lot of peptides and causes a bitter flavor of cheese. Bacteria have the potential to produce extracellular protease enzymes which have milk-clotting activity (MCA) (Daroit et al.,2012).

Lactic Acid Bacteria (LAB) is very potential to be developed in the production of rennin-like protease (RLP) because it is a safe and non-pathogenic bacterium. Some microbes that have commercially produced RLP are Bacillus cereus, Rhizomucor miehei, Endothia parasitica, Rhizomucor pusillus, Irpex lacteus, and Aspergillus oryzae (Jacob et al., 2011). Therefore, efforts are needed to explore the potential of existing microbes to be used as biological agents in enzyme production. Some LAB strains that are reported to have MCA capabilities are Pediococcus acidilactisi (Endakim et al., 2014), Enterococcus faecium isolated from Bakasam (Wendry et al., 2017), and Lactobacillus plantarum 1.13 (Wendry et al., 2020).

Goat's milk is an indigenous source of protein which have many $\mathrm{LAB}$, so it is very interesting to explore the potential of LAB from goat's milk for the production of RLP. Furthermore, it is necessary to carry out enzyme purification efforts to obtain enzymes 
with high activities. The RLP enzyme is expected to have a higher MCA compared to proteolytic activity (PA), so that the MCA/PA comparison value information is needed to get enzymes that can replace rennin in the cheesemaking process.

\section{Materials and Methods}

\section{Isolation of Lactic Acid Bacteria (LAB)}

LAB was isolated from goat's milk and was screened through spread plate cultivation on MRS agar media containing 3\% skim milk at $37^{\circ} \mathrm{C}$ for $24 \mathrm{~h}$. The obtained isolates exhibited a clear zone and clotting characteristic around $\mathrm{LAB}$ colonies which was an indication that the protease produced by LAB has milk-clotting activity. Furthermore, morphological observations were also carried out using a microscope (1000X).

\section{Milk-Clotting Activity (MCA) Tests}

Crude enzyme RLP was obtained through the production using MRS broth at an incubation temperature of $37{ }^{\circ} \mathrm{C}$ for $24 \mathrm{~h}$. Centrifugation of $10,000 \mathrm{~g}$ for $30 \mathrm{~min}$ at $4{ }^{\circ} \mathrm{C}$ was carried out in which the supernatant was a crude enzyme. As much as $5 \mathrm{~mL}$ milk with $12 \%$ dry matter content was added by $0.5 \mathrm{~mL}$ enzyme RLP at a temperature of $37{ }^{\circ} \mathrm{C}$. Furthermore, the milk-clotting time was observed and recorded. The milk-clotting activity was determined using the formula: SU (Soxhlet Unit): $\mathrm{SU}=2400 \times 5 \times \mathrm{D} / \mathrm{T} \times 0.5$, where $\mathrm{T}$ is milk-clotting time (s), and $\mathrm{D}$ is the dilution of the enzyme (El-Tanboly et al., 2013)

\section{Identification of 16S rRNA Gene}

The identification stages included DNA extraction and 16S rRNA gene amplification using PCR. For 16S rRNA gene sequencing, primers $8 \mathrm{~F}$ (5'AGAGTTTGATCATGGCTC AG-3'; positions 8 to $27 \quad \mathrm{bp})$ and 15R (5'- AAGGAGGTGATCCAACCGCA-3'; positions 1541 to $1522 \mathrm{bp}$ ) were used to amplify partial length gene of bacterial $16 \mathrm{~S}$ rRNA fragment. Each $25 \mu \mathrm{L}$ of PCR mixture contained $10 \mathrm{mM}$ Tris- $\mathrm{HCl}(\mathrm{pH} 8.3), 50 \mathrm{mM}$ $\mathrm{KCl}, 1.5 \mathrm{M} \mathrm{MgCl}_{2}, 200 \mu \mathrm{M}$ of each dNTP, $400 \mathrm{nM}$ of each primer, $1 \mathrm{U}$ of Taq polymerase, and $10 \mathrm{ng}$ of DNA tamplate. The PCR was operated at $96{ }^{\circ} \mathrm{C}$ for $5 \mathrm{~min}$, and performed 35 cycles consisting of $96^{\circ} \mathrm{C}$ for 1 min, $58{ }^{\circ} \mathrm{C}$ for $3 \mathrm{~min}$, and $72{ }^{\circ} \mathrm{C}$ for $1 \mathrm{~min}$; and $72{ }^{\circ} \mathrm{C}$ for $7 \mathrm{~min}$. The PCR products were subjected to electrophoresis gel in 1\% agarose gel. Then, DNA sequencing and similarity analysis were carried out through BLAST analysis in NCBI. For phylogenetic analysis, the sequences were aligned by using MEGA $\mathrm{X}$ software.

\section{Protease Activity (PA)}

One unit of protease activity can be defined as the number of enzymes capable of producing one micromole of tyrosine per min. Samples enzymes $6 \mu \mathrm{L}$ of the RLP enzyme $L$. paracasei were added by $6 \mu \mathrm{L}$ Tris buffer $\mathrm{HCl}$ $(\mathrm{pH} 7.4,25 \mathrm{mM})$, then were mixed with $6 \mu \mathrm{L}$ of $1 \%(\mathrm{w} / \mathrm{v})$ casein substrat solution and were incubated at $37{ }^{\circ} \mathrm{C}$ for $30 \mathrm{~min}$. They were subsequently added by $12 \mu \mathrm{L}$ of trichloroacetic acid and centrifuged $10,000 \mathrm{~g}$ for $30 \mathrm{~min}$ at 4 ${ }^{\circ} \mathrm{C}$. Then, $143 \mu \mathrm{L}$ of reagent $\mathrm{A}\left(\mathrm{Na}_{2} \mathrm{CO}_{3}\right.$ solution and $\mathrm{Cu} . \mathrm{SO}_{4} .5 \mathrm{HO}$ (5:1) was added, 29 $\mu \mathrm{L}$ of Follin Ciocalteau reagent, and incubated for $15 \mathrm{~min}$ before measured at $540 \mathrm{~nm}$. The proteolityc activity was determined through

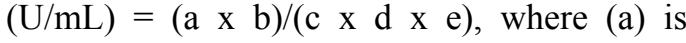
conversion of absorbance with standard of tyrosin $(\mathrm{mM}),(\mathrm{b})$ volume of reaction $(\mathrm{mL}),(\mathrm{c})$ volume of sample $(\mathrm{mL})$, (d) time of incubation $(\mathrm{min}),(\mathrm{e})$ total of volume $(\mathrm{mL})$.

\section{Protein Concentration (Enyard, 2008)}

Determination of protein concentration $(\mathrm{mg} / \mathrm{mL})$ using a BCA kit (bicinchoninic). The first step was to prepare the working reaction using a mixture of reagents A and B (50:1) (contains sodium carbonate, sodium bicarbonate, Pierce ${ }^{\circledR}$ BCA detection reagent, and sodium tartrate in $0.1 \mathrm{~N}$ sodium hydroxide). Then, a standard BSA curve was made with a concentration of $2000 \mu \mathrm{g} / \mathrm{mL}$, $1500 \mu \mathrm{g} / \mathrm{mL}, 1000 \mu \mathrm{g} / \mathrm{mL}, 750 \mu \mathrm{g} / \mathrm{mL}, 500$ $\mu \mathrm{g} / \mathrm{mL}, 250 \mu \mathrm{g} / \mathrm{mL}, 125 \mu \mathrm{g} / \mathrm{mL}, 25 \mu \mathrm{g} / \mathrm{mL}$ ), which working reaction $(1: 20)$ were added. The absorbance was measured at $540 \mathrm{~nm}$. The relationship between the BSA concentration (x) and the absorbance value (y) was obtained with the equation of the line: $Y=a x+b$. A mixture of sample and working reaction (1:20) was transferred into microplate 96-well, incubated at $37{ }^{\circ} \mathrm{C}$ for $30 \mathrm{~min}$, and analyzed for absorbance at $540 \mathrm{~nm}$ using ELISA reader (Thermo Multiskan Ex Brand).

\section{Enzyme Purification}


A sample $L$. paracasei 2.12 at exponential phase was inoculated $(0.1 \%)(\mathrm{v} / \mathrm{v})$ in MRS broth $100 \mathrm{~mL}$, incubated at $37{ }^{\circ} \mathrm{C}$ for $25 \mathrm{~h}$, and then centrifuged at $10.000 \mathrm{~g}$ for $30 \mathrm{~min}$ at $4{ }^{\circ} \mathrm{C}$. The enzyme was recuperated from crude supernatant by precipitation using $60 \%(\mathrm{w} / \mathrm{v})$ of solid ammonium sulphate, was resuspensed in $25 \mathrm{mM}$ Tris- $\mathrm{HCl}$ with $\mathrm{pH} 7.4$ and was dyalized in cellulose membrane of MCO 12.5 $\mathrm{kD}$ (Sigma-Aldrich). The results of the dialysis were fractionated using a Sephadex G-50 column pre-equilibrated with $25 \mathrm{mM}$ Tris- $\mathrm{HCl}$ $\mathrm{pH}$ 7.4. The volume of each fraction was 0.6 $\mathrm{mL}$ and then analyzed proteolytic activity, milk-clotting activity and protein content.

\section{SDS-PAGE and Zymography}

To determine the molecular weight of enzyme proteins, SDS-PAGE and zymogram with casein substrate using $12 \%$ polyacrylamide gel were carried out. The first step was to prepare the gel for SDS-PAGE and Zymogram. For the zymogram gel, casein as the substrate $(3 \mathrm{mg} / \mathrm{mL})$ was added to the gel. Furthermore, the enzyme sample of $15 \mu \mathrm{L}$ was added with $10 \mu \mathrm{L}$ of loading dye and denatured by heating in a $95{ }^{\circ} \mathrm{C}$ water bath for 1 min. Furthermore, SDS-PAGE was runned and the gel was stained with silver staining. For the zymogram, renaturation was carried out by immersing the gel in Triton X-100 2.5\% $(\mathrm{v} / \mathrm{v})$ for $40 \mathrm{~min}$, and followed by incubation in $25 \mathrm{mM}$ Tris $\mathrm{HCl}, 10 \mathrm{mM} \mathrm{pH} \mathrm{6,10} \mathrm{mM} \mathrm{CaCl} 2$ buffer at $37{ }^{\circ} \mathrm{C}$ for $12 \mathrm{~h}$. Gel staining was conducted using $0.05 \%$ Coomassie Blue solution for $2 \mathrm{~h}$. The clear protein band indicates that the band is an enzyme with proteolytic activity.

\section{Results}

A LAB isolate (Isolate 2.12) was successfully isolated from Ettawa goat milk with milk-clotting activity. The clotting zone around the LAB colony provided a strong initial indication that the bacterial isolate was capable of producing extracellular proteases which have milk coagulation activity (Figure 1). The identification of isolate 2.2 using the $16 \mathrm{~S}$ rRNA gene sequence showed 99\% identical to Lactobacillus paracasei (Figure 2).

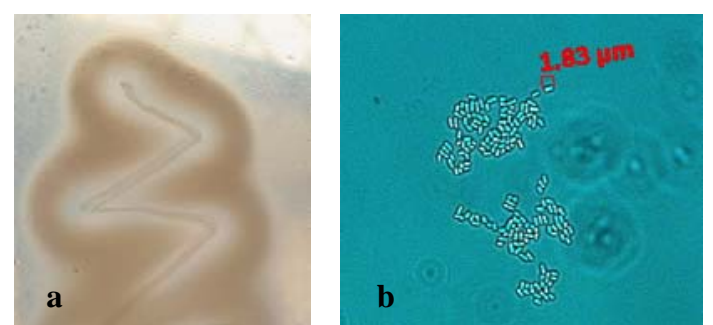

Figure 1. Isolate LAB 2.12 of $L$. paracasei on skim milk agar (a) and the micrographic of cells observed by microscope (1000X) (b).

The characteristics of $L$. paracasei 2.12 with the ability to produce RLP were almost the same as those of Paenibacillus spp. BD3526 strain that showed a clear zone around the colony and a precipitation zone (Hang et al., 2016). L. paracasei 2.12 isolated from goat milk had a bacillus shape with a cell size of $1.83 \mu \mathrm{m}$.

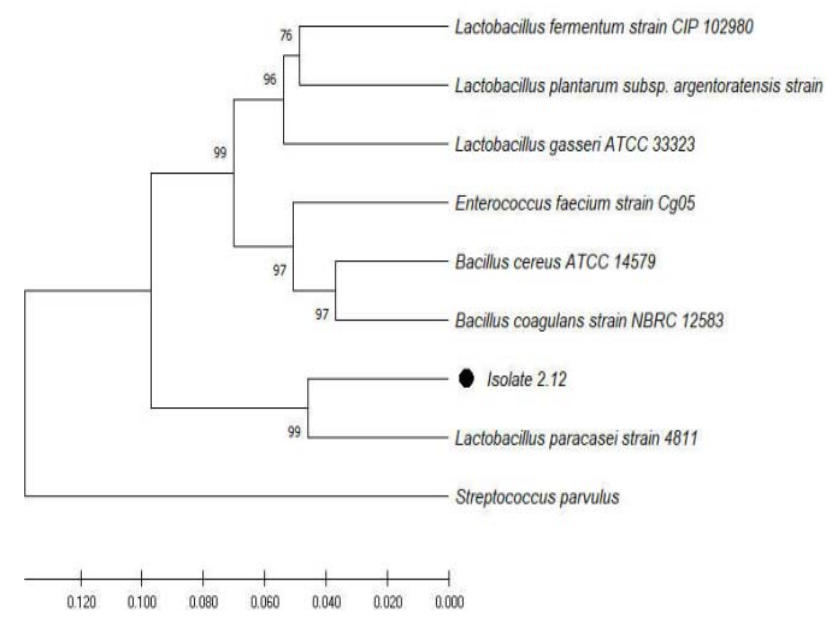

Figure 2. Phylogenetic tree of isolate 2.12 based on 16S rDNA gene sequence by using MEGA.10

The RLP L. paracasei 2.12 has a potential milk-clotting activity (MCA) value of 105.26 $\mathrm{SU} / \mathrm{mL}$ (Figure 3). As a comparison, it was reported that Mucor pusillus QM436 produced crude rennin-like protease with MCA of 50 $\mathrm{SU} / \mathrm{mL}$ (El-Tanboly et al. 2013). Moreover, The crude enzyme produced by Bacillus stearothermophilus has an MCA value of 24.23 SU/mL (Narwal et al., 2016). 

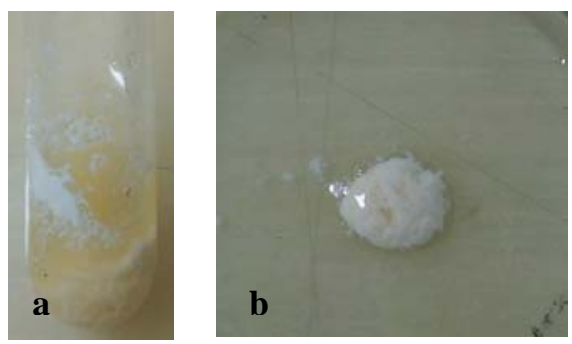

Figure 3. Milk-clotting activity crude RLP L. paracasei (a) Milk Clotting Activity Test (b) Characteristic of curd

The curd obtained from the coagulation process showed a good level of cohesiveness. The cohesiveness of the curd also determines the next processes in cheesemaking, which are cutting and pressing.

\section{The Purification of Rennin-Like Protease}

The production of the RLP L. paracasei 2.12 used MRS broth media with incubation at $37{ }^{\circ} \mathrm{C}$ for $24 \mathrm{~h}$ with a batch system without shaking. Then centrifugation was carried out at a speed of $10,000 \mathrm{~g}$, with a temperature of $4{ }^{\circ} \mathrm{C}$ for $30 \mathrm{~min}$ and the supernatant obtained was a crude RLP. The extract of crude RLP had an MCA activity of $105.26 \mathrm{SU} / \mathrm{mL}$ and a proteolytic activity (PA) of $17.57 \mathrm{U} / \mathrm{mL}$. One unit of protease activity can be defined as the number of enzymes capable of producing one micromole of tyrosine per minute (min). MCA testing is a quantitative test of enzyme activity. The main factor that determines the MCA value is the speed at which the milk is coagulated (skim). In the MCA test, the factor being measured is the clotting speed $(t)$ in seconds (sec).

In the deposition of $60 \%$ ammonium sulfate, it produced RLP with the highest activities of MCA of $250.00 \mathrm{SU} / \mathrm{mL}$ and of PA of $23.51 \mathrm{U} / \mathrm{mL}$. The increased use of ammonium sulfate resulted in increased yields, but overuse can cause damage to the structure of the enzyme protein and result in decreased activity. The result of $60 \%$ ammonium sulfate deposition was carried out with a buffer outside the bag $10 \mathrm{mM}$ Tris $\mathrm{HCl} \mathrm{pH} 7.4$ to remove residual salt and the results of increased activity were MCA of 272.73 $\mathrm{SU} / \mathrm{mL}, \mathrm{PA}$ of $53.18 \mathrm{U} / \mathrm{mL}$.

Fractionation was carried out in 25 fractions with a volume per fraction of 0.60 $\mathrm{mL}$. Meanwhile, the highest MCA activity was at fraction 10 of $300 \mathrm{SU} / \mathrm{mL}$ with PA of 66.84
$\mathrm{U} / \mathrm{mL}$. These results showed that RLP has a proteolytic activity that was not too high, but it has the ability to coagulate milk (casein). A strong proteolytic activity would excessively hydrolyze casein, resulting in reduction of curd forming (Hang et al., 2016).

The purification results of the RLP $L$. paracasei 2.12 showed an increase in purity of 10.99 times with a yield of $1.9 \%$. Purification of proteases from Mucor pusillus using ionexchange chromatography with QEAESephadex A-50 gave optimal results with a purity level reaching 17.31, while using filtration gel produced a purity of 7.68 (Nouani et al., 2011).

Table 1. The purification stage of the RLP L. paracasei 2.12

\begin{tabular}{|c|c|c|c|}
\hline Purification Step & $\begin{array}{l}\text { Vol } \\
(\mathrm{mL})\end{array}$ & $\begin{array}{l}\text { Protein } \\
(\mathrm{mg} / \mathrm{mL})\end{array}$ & Total Protein \\
\hline Crude Extract & 90 & 3.94 & 355.05 \\
\hline $\begin{array}{l}\text { Ammonium } \\
\text { sulfate }(60 \%)\end{array}$ & 0.8 & 9.20 & 7.36 \\
\hline Dialysis & 0.8 & 6.61 & 5.29 \\
\hline G-50 Sephadex & 0.6 & 1.02 & 0.61 \\
\hline Purification Step & $\begin{array}{l}\mathrm{MCA} \\
(\mathrm{SU} / \mathrm{mL})\end{array}$ & $\begin{array}{l}\text { Total } \\
\text { MCA }\end{array}$ & $\begin{array}{l}\text { Specific MCA } \\
(\mathrm{SU} / \mathrm{mg})\end{array}$ \\
\hline Crude Extract & 105.26 & 9473.40 & 26.68 \\
\hline $\begin{array}{l}\text { Ammonium } \\
\text { sulfate }(60 \%)\end{array}$ & 250.00 & 200.00 & 27.15 \\
\hline Dialysis & 272.73 & 218.18 & 41.20 \\
\hline G-50 Sephadex & 300.00 & 180.00 & 293.25 \\
\hline Purification Step & $\begin{array}{l}\text { PA } \\
(\mathrm{U} / \mathrm{mL})\end{array}$ & $\begin{array}{l}\text { Total } \\
\text { PA }\end{array}$ & $\begin{array}{l}\text { Specific PA } \\
(\mathrm{U} / \mathrm{mg})\end{array}$ \\
\hline Crude Extract & 17.57 & 1581.30 & 4.45 \\
\hline $\begin{array}{l}\text { Ammonium } \\
\text { sulfate }(60 \%)\end{array}$ & 23.51 & 18.80 & 2.55 \\
\hline Dialysis & 53.18 & 42.54 & 8.04 \\
\hline G-50 Sephadex & 66.84 & 40.10 & 65.73 \\
\hline Purification Step & Purity & Yield & $\mathrm{MCA} / \mathrm{PA}$ \\
\hline Crude Extract & 1 & 100 & \\
\hline $\begin{array}{l}\text { Ammonium } \\
\text { sulfate }(60 \%)\end{array}$ & 1.01 & 2.11 & \\
\hline Dialysis & 1.54 & 2.30 & \\
\hline G-50 Sephadex & 10.99 & 1.90 & 4.48 \\
\hline
\end{tabular}

The SMCA/SPA value of the RLP $L$. paracasei 2.12 was 4.48 higher than that of the calf rennet with a ratio value of 1 and Mucor pusillus QM 436 with a value of 1.81 (ElTanboly et al. 2013). The SMCA/SPA ratio is one of the important criteria for evaluating the potential of the enzyme as a substitute for rennet (He et al., 2012). 


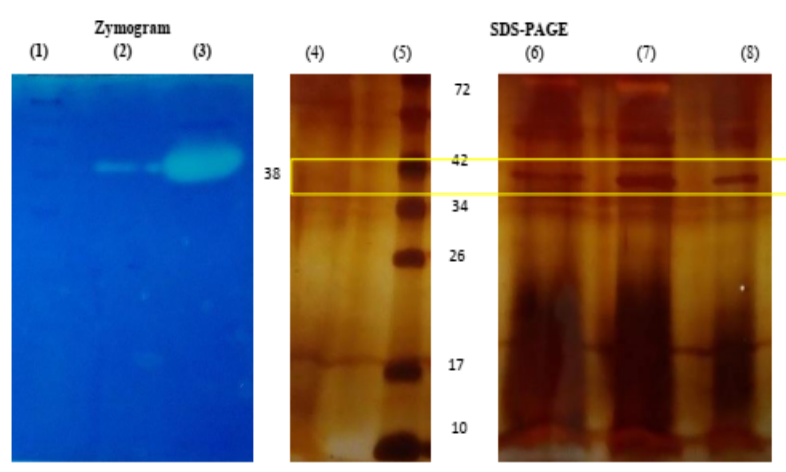

Figure 4. Zymogram (caseins): Marker (1), Fraction 10 (2), Dialysis (3). SDS-PAGE (silver staining): Fraction 10 (4), Marker (5), Crude enzyme (6), Ammonium sulfate $60 \%$ (7), Dialysis (8).

The results of purification of the RLP $L$. paracasei 2.12 by using purification stages of deposition of $60 \%$ ammonium sulfate, dialysis, and subsequently gel filtration chromatography with Sephadex G-50 showed one enzyme protein band with size of $38 \mathrm{kDa}$ on SDSPAGE and zymogram as shown in Figure 4. The zymogram used incubation at optimum temperature and optimum $\mathrm{pH}$ so that the dialysis results showed a high band intensity, while the results of the gel filtration on fraction 10 showed a low-intensity band. This was due to the dilution of the gel filtration process as shown clearly in the calculations in Table 1 of the total dialysis protein $(5.29 \mathrm{mg})$ and gel filtration $(0.61 \mathrm{mg})$. As a comparison, the RLP produced by Bacillus subtillis MTCC 10422 had a molecular weight of $27 \mathrm{kDa}$ (Narwal et al., 2016) and the RLP produced by Paenibacillus spp. strain BD3526 showed a 5 $\mathrm{kDa}$ protein band on SDS-PAGE and gelatin zymography (Hang et al., 2016).

\section{Discussion}

The process of making cheese varies greatly, but the principal stages include: pasteurization of milk, clumping of casein, separation of whey, molding, pressing, soaking with saline/ salting, and ripening. The types of cheese in the world have been identified as 750 types (varieties) (Fox et al., 2017). Based on the coagulating agent used, types of cheese can be divided into two: a) rennet-coagulated cheese, the majority of types of cheese $(75 \%$ of cheese products in the world); and b) acidcoagulated cheese, e.g. Cottage and Quarg (Fox et al., 2017).
The mechanism of milk clotting by enzymes is different from that by acids. In the first step, renin cleaves peptide bonds between phenylalanine (Phe) and methionine (Met) $\left(105^{\text {th }}\right.$ to $106^{\text {th }}$ sequences) from casein polypeptides, producing para-k-casein and macropeptides. In the second stage, macropeptides produced from these cuts are water-soluble, while the $\kappa$-casein will settle. Casein instability occurs due to the breaking of Phe and Met bonds so that the other casein fraction settles (Fox et al., 2017).

In the process of making cheese, milk clotting by rennet is expected to be formed in 30-40 min incubation time. Some commercial rennet brands produce cheese with a range of $10-11 \%$. The percentage of curd produced in the cheesemaking process is one of the important parameters because it is related to economic value and efficiency in the cheese industry.

Rennin production from calves is decreasing in the world, resulting in high prices for these enzymes. Hence, efforts have been made to look for alternative enzymes (substitute). Protease enzymes other than rennin which have activities similar to rennin, namely milk-clotting activity, are known as rennin-like protease (RLP). RLP can be obtained from plant and microbial sources.

RLP from plant sources have characteristics with high proteolytic activities. They are known as papain (papaya) and bromelain (pineapple). There are some disadvantages in using plant protease including their highcontent protease activity, excessive hydrolysis process, and hydrophobic production that lead to a bitter taste in the cheese products (Sousa et al., 2001). However, these obstacles can be overcome by controlling the use of the enzyme either by limiting its concentration or by looking for reaction conditions that are not optimum to inhibit its activity.

There are RLP produced by microbes that have characteristics similar to rennin from the calf's stomach and produce curd products from milk similar to those produced by animal rennin. Rhizomucor miehei, Rhizomucor pusillus, Endothia parasitica, Aspergillus oryzae, and Irpex lacteus have been produced commercially to produce microbial RLP (Jacob et al. 2011). RLP from rice wine breaks the peptide bonds between Thr94-Met95 which can be detected by mass spectrometry (MS) (Jiang et al., 2007). Fungal protease 
Cryphonectria parasitica cuts peptides in Ser104-Phe105 in к-CN (Garg \& Johri, 1994).

Raw goat milk is a potential source of lactic acid bacteria $(\mathrm{LAB})$ that produce antibacterial compounds. Moreover, Lactococcus strains from milk produce variants of antibacterial nisin which have a broad spectrum and can be used as a biopreservative (Perin et al., 2014). The initial screening to explore the potential of the isolated microbes from milk, such as LAB strains using skim milk agar media has been widely applied. This technique can determine the ability of microbial isolates to produce enzymes extracellularly by adding specific substrates to the growing media (solid media/agar).

In the screening of LAB strains isolated from milk for their proteases potential, casein was added approximately $2-3 \%$ to agar media. LAB isolates exhibited clear zones around their colonies, indicating the potential of these isolates to produce extracellular proteases. The screening technique only shows that microbial isolates can produce clear zones around their colonies. The screening of bacterial isolates in the early stages can use agar media with the addition of the casein substrate. This method has been carried out to obtain isolates with the potential of producing extracellular proteases. Casein as a substrate has been used for screening of some protease-producing microbes (Verma et al., 2001; Chi et al., 2007; Sindhu et al., 2009).

In general, the purification of RLP includes the deposition of ammonium sulfate, dialysis, and chromatography. Precipitation using salt is based on the solubility of proteins that interact polar with water molecules, the ionic interactions of proteins with salt, and the repulsion of rejecting proteins with the same charge. Protein solubility (at certain $\mathrm{pH}$ and temperature) increased as the salting in concentration increased. An increase in solubility of the protein will increase the strength of the ionic solution. The addition of certain salts will cause protein solubility to decrease (salting out). Water molecules that bind with more salt ions eventually cause the withdrawal of the water casing that surrounds the surface of the protein, thereby causing the proteins to interact, aggregate, and then settle. Ammonium sulfate is the most commonly used salt to precipitate proteins because it has a high solubility in water and relatively inexpensive (Scopes, 1987).

\section{Conclusion}

Purification of RLP L paracasei with $60 \%$ ammonium sulphate deposition, dialysis, and filtration gel chromatography Sephadex G-50 showed a single $38 \mathrm{kDa}$ protein band with SMCA/SPA 4.48. This finding suggested that RLP L. paracasei has a remarkable potential to be developed as an alternative to rennin in cheese making.

\section{Acknowledgements}

The research was funded by KKP3N Program from Indonesian Agency for Agricultural Research and Development (IAARD), Ministry of Agriculture fiscal year 2016. All facilities were supported by Research Center for Biotechnology-Indonesian Institute of Sciences (LIPI).

\section{References}

Chi, Z., Ma, C., Wang, P., \& Li, H.F. (2007). Optimization of medium and cultivation conditions for alkaline protease production by the marine yeast Aureobasidium pullulans. Bioresources. Technology, 98, 534-538.

Daroit, D. J., Correa, A. P.F.Canales, M. M., Coelho, J. G., Hidalgo, M. E., Tichota, D. M. (2012). Physicochemical properties and biological activities of ovine caseinate hydrolysate. Dairy Science and Technology. 92, 335-351.

El-Tanboly, E. S., El-Hofi, M., Youssef, Y. B., ElDesoki, W., \& Ismail, A. (2013). Utilization of salt whey from Egyptian ras (Cephalotyre) cheese in microbial milk clotting enzymes production. Acta Scientiarum Polonarum Technol Aligment 12(1), 9-19.

Endakim, M.M., Hassan, Z., Aween, M.M., Elshaafi, B.M., Muhialdin, B.J. (2014).Mik clotting and proteolytic activity of enzyme preparation from Pediococcus acidilactici $\mathrm{SH}$ for dairy products. African Journal of Biotechnology. 14(2) : 133-142.

Enyard, C.C. (2008). Sigma's non-specific protease activity assay-casein as a substrate. Journal of Visualized Experiments. (19) e899. http://dx.doi.org/10.3791/899.

Fox, P. F., Guinee, T. P., Cogan, T. M., \& Mc Sweeney, P. L. H. (2017). Fundamentals of cheese science. Second Edition. New York: Springer. 
Garg, S. K., \& Johri, B. N. (1994). Rennet: Current trends and future research. Food Reviews International.10, 313-355.

Hang, F., Liu, P., Wang, Q., Han, J., Wu, Z., Gao, C., Liu, Z., Zhang, H., Chen, W. (2016). High milk-clotting activity expressed by the newly isolated Paenibacillus spp. strain BD3526. Molecules. 21. 73. doi:10.3390/molecules21010073.

He, X., Zhang, W., Ren, F., Gan, B., Guo, H. (2012).Screening fermentation parameters of the milk-clotting enzyme produced by newly isolated Bacillus amyloliquefaciens D4 from the Tibetan Plateau in China. Ann. Microb.62:357365.

Jacob, M., Jaros, D., \& Rohm, H. (2011). Recent advances in milk clotting enzymes. International Journal of Dairy Technology. 64,14-33.

Jiang, T.L., Chen, J., \& Xue, L. (2007).Studi of milk-clotting mechanism of rennet-like enzyme from glutinous rice wine: Proteolytic property and the cleavage site on k-casein.Jounal of Dairy Science. 90, 3126-3133.

Narwal, R. K., Bhushan, B., Pal, A., Panwar, A., \& Malhotra, S. (2016). Purification, physicochemico-kinetic characterization and thermal inactivation thermodynamics of milk clotting enzyme from Bacillus subtillis MTCC 10422.LWT. Food Science and Technology. 65, 652-660. http://dx.doi.org/10.1016/j.lwt.2015.08.065.

Nouani, A., Mati, F. M., Belbraouet, B., \& Bellal, M. M. (2011). Purification and characterization of a milk-clotting protease from Mucor pusillus:
Method comparison. African Journal of Biotechnology.. 10(9), 1655-1665.

Perin, L.M., Nero, L.A. (2014).Antagonistic lactic acid bacteria isolated from goat milk and identification of a novel nisin variant Lactococcus lactis. BMC Microbiology 14:36.

Sousa, M. J., Y. Ardö, and P. L. H. McSweeney. (2001). Advances in the study of proteolysis during cheese ripening. Int. Dairy J. 11:327345

Sindhu, R., Suprabha, G. N., \& Shashidhar, S. (2009). Optimization of process parameters for the production of alkaline protease from Penicillium godlewskii SBSS 25 and its application in detergent industry. African Journal of Microbiology Research. 3(9), 515522.

Scopes, R. K. (1987). Protein purification principles and practice. $2^{\text {nd }}$ Edition. New York: Springer Verlag.

Verma, R., Sil, K., Pandey, A. K., \& Rajak, R. C. (2001). Solid state fermentation to produce alkaline protease by Aspergillus fumigatus B149. India Journal Microbiology. 41, 111-114.

Wendry, S. P., Kusmajadi, S., Hartati, C., Apon ,Z. M., Puspo, E. G., Harsi, D. K., \& Maggy, T.S. (2017). Enterococcus faecium 1.15 isolated from bakasam showed milk clotting activity. Annales Bogoriensis. 21(1),9-14.

Wendry, S. P., Maggy, T. S., Harsi, D. K., Puspo, E. G., \& Apon, Z. M. (2020). A novel rennin like protease from Lactobacillus plantarum 1.13 isolated from Indonesian fermented meat (Bakasam). Biocatalysis and Agricultural Biotechnology. 29. https://doi.org/10.1016/ j.bcab.2020.101818 